\title{
İlkokul Matematik Öğretim Programının Sayı Duyusu Temel Bileşenlerine Göre İncelenmesi
}

\section{Examining of Primary School Mathematics Curriculum According to the Basic Components of Number Sense}

\author{
Hatice Çetin $^{1}$ \\ Şeyma Öztürk ${ }^{2}$
}

Alıntılama: Çetin, H. \& Öztürk, Ş. (2020). İlkokul matematik öğretim programının sayı duyusu temel bileşenlerine göre incelenmesi. Ulusal Ĕgitim Akademisi Dergisi (UEAD), 4(2), 163-180.

Geliş tarihi:

11.08.2020

Kabul tarihi: 19.10.2020

(C) UEAD 2020

Tüm hakları saklıdır.
Özet: Bu çalışmanın amacı 2018 yılında son güncellemesi yapılan ilkokul matematik dersi öğretim programında yer alan kazanımları sayı duyusu temel bileşenlerine göre incelemektir. Bu amaç doğrultusunda araştırma nitel araştırma yöntemi durum çalışması desenine uygun olarak yürütülmüştür. İlkokul matematik programındaki tüm kazanımlar sınıf düzeyi ve öğrenme alanları bazında sayı duyusu bileşenlerine göre detaylı olarak incelenmiştir. Veriler betimsel analiz yoluyla analiz edilmiştir. Program bir alan uzmanı ve sayı duyusu ile ilgili yüksek lisans dersi almış iki sınıf öğretmeni tarafından incelenmiştir. Çalışma sonucunda öğretim programında; en fazla sayı duyusu bileşeninin yer aldığı sınıf düzeyinin 2. Sınıf olduğu görülmüştür. Sayılar ve işlemler öğrenme alanında 32, ölçme öğrenme alanında 7 kazanım sayı duyusu ile ilişkilendirilmiştir. Sayıların anlamı bileșenine uygun 12, sayıların büyüklügü bileşenine uygun 8 , esnek işlem yapma ve sonucun akla yatkınlığın yargılama bileşenine uygun 7 , tahmin etme bileşenine uygun 12 kazanıma ulaşılmıştır. Genel olarak ilkokul matematik programında, bu çalışma kapsamında referans aldığımız sayı duyusu bileşenlerine doğrudan işaret eden kazanımlar net olmamakla birlikte pek az bulunmuştur.

Anahtar kelimeler: Sayı duyusu, ilkokul, matematik program.

Abstract: The aim of this study is to examine the achievements in the primary school mathematics curriculum, which was last updated in 2018, according to the basic components of the sense of number. For this purpose, the research was carried out in accordance with the qualitative research method case study pattern. In elementary

\footnotetext{
${ }^{1}$ (Sorumlu yazar)Dr. Öğr. Üyesi, Necmettin Erbakan Üniversitesi, haticebts@gmail.com, https://orcid.org/0000-0003-0686-8049.

2 Ögretmen, Milli Eğitim Bakanlığl, seymaozturk92@gmail.com, https://orcid.org/0000-0001-5576-054X.
} 


\begin{abstract}
Received:
11 August 2020

Accepted:

19 October 2020

(C) UEAD 2020

All rights reserved.

school mathematics curriculum all the gains are examined in detail according to class level and units. The data were analyzed through descriptive analysis. The program was examined by a domain expert and two primary school teachers who took a master course on number sense. As a result of the study, in the curriculum; it was seen that the class level with the highest number sense component was $2^{\text {nd }}$ grade. Numbers and operations unit is associated with 32 acquisitions and 7 acquisitions in measurement unit with number sense. 12 points suitable for the meaning of the numbers component, 8 suitable for the size component of the numbers, 7 appropriate for the judgment component of the plausibility of the result and 12 appropriate for the prediction component were achieved. In general, the achievements that point directly to the number sense components that we refer to within the scope of this study in primary school mathematics curriculum, although not clear, were few.
\end{abstract}

Keywords: Number sense, primary school, mathematics curriculum.

\section{Giriş}

Matematik denilince akla sadece kuralların doğrudan uygulandığı, çözümü sayfalarca süren işlemler gelebilir. Matematik, çarpım tablosunu ezberleyebilme, verilen kuralı hızlı bir şekilde uygulayabilme olarak düşünülmemelidir. Matematiğin kuralsal bilgileri ezberletmek ve işlemleri uygulatmaktan ziyade bir takım beceri ve yetkinlikleri kazandırmak gibi bir rolünün olduğu muhakkaktır. Matematik müfredatında da yer alan problem çözme, akıl yürütme, iletişim ve ilişkilendirme gibi beceriler kazandırılması hedeflenen önemli matematiksel becerilerdir (MEB, 2018).

2018 yılı Matematik Dersi Öğretim Programında, matematiksel okur yazar olma, matematiksel kavramları anlama, bu kavramları günlük hayatta kullanma, tahmin etme ve zihinden işlem yapma, esnek düşünme, kural temelli olmayan problem çözme becerileri vurgulanır (MEB, 2018). Ancak yapılan araştırmalar genelde öğrencilerin, programlarda amaçlanan günlük yaşam ve sınıf dışı durumlarda ihtiyaç duydukları beceriler ile ezberledikleri formülleri ilişkilendiremediklerini göstermektedir (Crouch \& Haines, 2004; Deniz, 2014; Güven \& Özçelik, 2017). Alışveriş yapan bir kişinin cüzdanındaki paralarını kontrol ederken market alışverişi için yeterli miktarda nakit parası olup olmadığına karar vermesi, pazardan alınan herhangi bir meyvenin ağırlığının veya yolculuk esnasında kalan yolun ne kadar süreceğinin tahmin edilmesi, marketteki ürünlerin fiyatlarının karşılaştırılması gibi birçok olay günlük hayatta karşılaşılan problemleri (Bresser \& Holtzman, 1999; akt: Çekirdekçi, 2015) çözmek için ezberlenmiş kural ve formüller yerine yuvarlama, sayıların anlam ve büyüklüklerini bilme, tahmin etme, zihinden işlem yapma 
İlkokul Matematik Öğretim Programının Sayı Duyusu Temel Bileşenlerine Göre İncelenmesi

gibi beceriler gerekmektedir. Bütün bu beceriler uluslararası literatürde sayı duyusu ile ilgili kavramlar olarak ifade edilmektedir ve günlük hayatta karşılaştığımız bu tür problemlerin çözümü sayı duyusunu gerektirmektedir (Çekirdekçi, 2015).

\section{Kuramsal Çerçeve}

Sayı duyusunun tanımı çok açık olmamakla birlikte ilk kez 1980’lerin sonlarına doğru kullanılmaya başlamıştır (van de Walle, Karp \& Bay-Williams, 2014:129). Howden (1989), sayı duyusunu, sayılar ve sayılar arası ilişkilerle ilgili bir sezgi olarak tanımlamıştır. Sayı duyusunun tipik özellikleri zihinden hesaplama ve tahmin (Case \& Sowder, 1990; Hope \& Sherrill, 1987; Sowder \& Wheeler, 1989; akt: Reys, Reys, Emanuelsson, Johansson, Mclntosh \& Yang, 1999) olarak belirtilmektedir. Sayı duyusu ile ilgili literatür, ortak temalar içermektedir. Literatürün bu ortak temaları doğrultusunda Reys vd. (1999), sayı duyusu bileşenlerini; sayıların anlam ve büyüklüklerini anlama, sayıların eşdeğer gösterimlerini anlama ve kullanma, işlemlerin anlam ve etkisini anlama, eşdeğer ifadeleri anlama ve kullanma, zihinden hesaplama, yazılı hesaplama ve esnek hesaplama ve sayma stratejileri, ölçüm referansları olarak belirlemişlerdir.

Sayı duyusu, sayıları kullanabilme becerisi, bireylerin günlük yaşamlarında karşılarına çıkabilecek sayısal problemleri çözebilmek için esnek ve akla yatkın çözüm yolları geliştirebilmeleri ve bu çözüm yollarını kullanabilmeleridir (McIntosh, Reys \& Reys, 1992; Yang, 2005).

Sayı duyusuna sahip çocukların özellikleri, NCTM (1989) tarafından sayıların anlamlarını bilme, saylar arasında ilişkiler kurma, sayıların büyüklüklerini fark etme, işlemlerin anlamlarını bilme, ölçüm için referans geliştirme olarak belirtilmiştir.

Matematik eğitiminde önemli bir yere sahip olan sayı duyusu, öğrencilerin gerçek hayatla bağ kurmalarını sağlamakta ve ilkokul eğitiminde anahtar bir rol üstlenmektedir (Yang, Hsu \& Huang, 2004). Geçmişten bugüne uygulanan öğretim programlarında sayı duyusu kavramına doğrudan yer verilmemektedir (Bayak, 2016; Can, 2017; Umay, Akkuş-Çıkla \& Duatepe, 2006; Yarımkaş, 2019). Sayı duyusu ile ilişkili becerilerin programda bulunması öğrencilerin sayı duyusu becerilerini geliştirmeleri açısından oldukça önemlidir.

Matematik Öğretim Programı öğrencilerin matematik öğrenim süreçlerini şekillendiren yapılardır. İlkokul matematik öğretim programında sayı duyusu üzerinde durulması öğrencilerin 
anlamlı öğrenmesini sağlayacaktır (Cheng \& Wang, 2012). Bu görüşler doğrultusunda ülkemizde öğrencilerin sayı duyusu becerilerinin incelenebilmesi için öncelikle Matematik Dersi Öğretim Programı'nın incelenmesinin önemli olduğu düşünülmüştür. Sayı duyusunun ilkokul matematik öğretim programındaki yeri konusunda ülkemizde yapılmış çalışma sayısı oldukça azdır. Harç (2010), yaptığı çalışmada Amerika, İngiltere, Türkiye ve New Jersey matematik müfredatında 1-6. sınıf kazanımları Reys vd. (1999) tarafından belirlenen sayı duyusu bileşenlerine göre incelemiştir. 2007 yılında güncellenen müfredattaki kazanımların incelendiği bu çalışmada 2. sınıfta beş, 3 . sınıfta 4, 4. sınıfta 5 kazanımın sayı duyusu ile ilişkili olduğu belirlenmiştir. Gülbağcı Dede'nin (2015) çalışmasında ilköğretim için 2009 programı, ortaöğretim için 2013 programı kazanımlarının sayı duyusuna uygunluğunu öğrenme alanları ve alt öğrenme alanları açısından incelenmiştir. Çalışmada ilkokul 1. sınıf için 21 kazanımın, 2. sınıf için 29 kazanımın, 3. sınıf için 24 kazanımın, 4. sınıf için 36 kazanımın sayı duyusu ile ilişkili olduğu belirtilmiştir. Çekirdekçi (2015) yaptığı çalışmasında 2012 yılında güncellenen matematik öğretim programındaki ilkokul 4. sınıf kazanımlarını Reys vd. (1999) tarafından belirlenen sayı duyusu bileşenlerine göre incelemiş̦tir. 14 kazanımın sayı duyusu bileşenlerine uygun olduğunu belirtmiştir. Şengül (2013) çalışmasında 2009 yılındaki programı sayı duyusu bileşenlerine ayırmadan incelemiş; 1 . sınıfta 2, 2. sinıfta 8,3 . sınıfta 8, 4. sınıfta 14 kazanımın sayı duyusu ile ilişkili olduğunu belirtmiştir.

Peker (2019) çalışmasında 2018 ortaokul matematik programındaki kazanımları Reys vd. (1999) tarafindan belirlenen sayı duyusu bileşenleri ve Greeno'nun (1991) niceliksel muhakeme ve çıkarım bileşeni temel alarak incelemiştir. Karabey, Tunalı, Olkun ve Ergut (2019) çalışmasında 2009-2013-2017 yılındaki ortaokul matematik öğretim programlarını Yang (1995) tarafından belirlenen sayı duyusu bileşenlerine göre karşılaştırmışlardır. Diğer taraftan İlkokul matematik dersi programlarının (1926-2015 yılları arası) sayılar öğrenme alanına göre karşılaştırıldığı bir betimsel analiz mevcuttur (Osmanoğlu, 2016:237). Konu ile ilgili yapılan çalışmalardan, güncel ilkokul matematik programı kazanımlarının sayı duyusu açısından ele alınmadığı anlaşılmaktadır. Halbuki, sayı duyusu temel matematiksel bir beceri, bir sezgi olarak kritik dönemlerde yani ilkokul dönemlerinde kazandırılmaya başlandığı belirtilmektedir (van de Walle, vd., 2014, s.129). Bu sebepten ilkokul programındaki sayı duyusunun betimsel analizinin önemli olduğu düşünülmektedir. Diğer yandan öğretmenlerin sayı duyusunun yetersiz olmasından ve öğrencilere sayı duyusunu geliştirmede nasıl yardım edeceklerini bilmemelerinden dolayı öğrencilerin sayı 
İlkokul Matematik Öğretim Programının Sayı Duyusu Temel Bileşenlerine Göre İncelenmesi

duyusunun geliştirilemediği belirtilmiştir (Yang, 2007). İşte bu noktada, öğretim programları, öğretmene öğreteceği konu ile ilgili alternatifler sunan, hangi yolun veya yöntemin uygun olduğunun ipuçlarını veren yön göstericilerdir (Baki, 2019:22). Bu açıdan matematik program çalışmaları önem arz etmektedir.

Bu çalışmanın problem durumu kritik dönemde (ilkokul) verilmesi önemli olan (Yang, Hsu, \& Huang, 2004) sayı duyusunun ilkokul matematik programında ne düzeyde verildiğidir. Bu doğrultuda, 2018 yılı ilkokul matematik öğretim programı kazanımları, esasen sayı duyusu literatüründen ortaya çıkarılan ortak temalarla (Mcintosh, vd., 1992; Reys, vd., 1999) belirlenen Gülbağcı Dede ve Şengül'ün (2016) yeniden revize ettiği dört sayı duyusu bileşenine göre incelenmiştir. Programdaki kazanımlarda sınıf düzeyine ve öğrenme alanlarına göre sayı duyusu bileşenlerine (sayıların anlamı, sayıların büyüklüğü, esnek işlem yapma ve sonucun akla yatkınlığını yargılama, tahmin) ne ölçüde yer verildiğinin tespit edilmesi amaçlanmıştır.

\section{Yöntem}

\section{Araştırmanın Modeli}

$\mathrm{Bu}$ çalışma, nitel araştırma yöntemi olup durum çalışması olarak sunulmuştur. Durum çalışması, güncel hayat ve bağlamın içindeki bir durumun araştırılması ile ilgilidir (Creswell, 2015:99). Bu çalışma da güncel matematik programının sayı duyusu açısından incelendiği bir durum çalışmasıdır.

\section{Veri Toplama}

Veriler nitel araştırma çalışmasında kullanılan bir veri toplama tekniği olan doküman incelemesi yoluyla toplanmıştır. Doküman incelemesi, nitel araştırmada tek başına kullanılabilen bir veri toplama tekniğidir (Yı1dırım \& Şimşek, 2006:187). Çalışma kapsamında önceden belirlenmiş temalara göre ayrıntılı incelenen doküman, Milli Eğitim Bakanlığı 2018 İlkokul Matematik dersi Matematik Programı'dır.

\section{Veri Analizi}

Toplanan veriler betimsel analiz tekniğine göre analiz edilerek sistematik bir şekilde bulgular ortaya koyulmuştur. Betimsel analize göre veriler önceden literatürde tespit edilmiş temalara göre kodlanır (Yıldırım \& Şimşek, 2006:224). Bu çalışmada ilgili program kazanımları 
literatürde mevcut kabul görmüş önceden belirlenmiş olan ortak sayı duyusu bileşenleri 1şığında (Mcintosh, vd., 1992; Reys, vd., 1999), Gülbağc1 Dede ve Şengül'ün (2016) analiz yapmayı kolaylaştırmak için sadeleştirdiği temalar çerçevesinde analiz edildiğinden betimsel analiz kullanılmıştır.

Bu çalışmada da bu dört bileşen esas alınarak kodlama yapılmıştır. Bu bileşenler ve açıklamaları aşağıdadır.

Tablo 1. Sayı Duyusu Bileşenleri ve Açıklamaları

\begin{tabular}{|c|c|}
\hline Sayı duyusu bileşeni & Açıklama \\
\hline Sayıların anlamı & $\begin{array}{l}\text { "Sayılar, kesirler ve ondalık sayıları içeren onluk sayı sistemini, basamak } \\
\text { değerini, sayı örüntülerini ve sayıların farklı temsillerini ihtiva eder. } \\
\text { Örneğin; bir sayının eş değer gösterimleri (1/4=0,25=\%25 gibi); sayılar } \\
\text { arasındaki ilişkilerin keşfedilmesi (8, 16'nın yarısı ve 2'nin küpü olduğunu } \\
\text { bilme), sayıyı parçalama/bileştirme (26 sayısını } 26=(100 \div 4)+1 \text { şeklinde } \\
\text { gösterme), basamak değerini kavrama (162 sayısını 100+60+2 formunda } \\
\text { düsünebilme) bu bileşen kapsamındadır." }\end{array}$ \\
\hline Sayıların büyüklüğ̈̈ & $\begin{array}{l}\text { "Sayılar, kesirler ve ondalık sayılarl ya da sayılarla oluşturulan ifadeleri } \\
\text { büyüklük olarak karşılaştırmayl, küçükten büyüğe/büyükten küçüğe doğru } \\
\text { sıralamayl, sayıları birbirine olan uzaklıklarını karşılaştırmayl } \\
\text { içermektedir. Bu bileşene; 0,55'in 0,6'tan kü̧̧ük olduğunu bilme, kesirleri } \\
\text { büyüklük olarak karşılaştırma, 22'nin 23'e 22'den daha uzak olduğunu } \\
\text { fark etme örnek olarak verilebilir." }\end{array}$ \\
\hline $\begin{array}{l}\text { Esnek işlem yapma ve sonucun } \\
\text { akla yatkınlığını yargılama }\end{array}$ & $\begin{array}{l}\text { "Kastedilen matematiksel hesaplamalarda sonuca ulaşmak ve sonucu } \\
\text { yargılamak için sayı ve işlem bilgisini kullanarak zihinden işlem, tahmin } \\
\text { etme gibi becerileri ile esnek işlem yapılmasıdır. Örneğin 1/3'ten küçük ü̧ } \\
\text { kesrin toplamının l'den küçük olduğunu fark etme, } 0 \text { ile } 1 \text { arasındaki bir } \\
\text { sayı ile çarpmanın sonucu küçülttüğ̈̈̈nü bilme, iki sayının çarpımı } \\
\text { sorulduğunda sayıları yuvarlayarak yakın bir sonuç bulma bu bileşen } \\
\text { kapsamında yer almaktadır." }\end{array}$ \\
\hline Tahmin etme & $\begin{array}{l}\text { "Tahmin etme, bir şeyin büyülüğü ya da ölçüsü hakkında saymadan ve } \\
\text { ölçüm yapmadan hızlı ve akla yatkın bir şekilde fikir yürütmektir. Tahmin } \\
\text { etme bileşenine } 10 \mathrm{katl} \text { bir apartmanın yüksekliğinin, } 20 \text { sinıflı bir }\end{array}$ \\
\hline
\end{tabular}


İlkokul Matematik Öğretim Programının Sayı Duyusu Temel Bileşenlerine Göre İncelenmesi

\begin{tabular}{|l|l|}
\hline & $\begin{array}{l}\text { okuldaki ögrenci mevcudunun, haritada iki şehir arasındaki uzaklı̆̆ın } \\
\text { tahmin edilmesi gibi örnekler verilebilir. },\end{array}$ \\
\hline
\end{tabular}

Gülbağcı Dede ve Şengül'den (2016) alıntıdır.

İlkokul Matematik Öğretim programında yer alan kazanımlar incelenirken yukarıdaki bileşenler ve açıklamaları doğrultusunda kodlanarak analiz edilmiştir. Kazanımlar sayı duyusu ile ilişkilendirilebilecek ifadeler içermesi ya da kazanım açıklamasında sayı duyusu ile ilişkilendirilebilecek bir bilgi yahut örnek verilmesi dikkate alınmıştır.

Örneğin, aşağıdaki örnekte görüldüğü üzere 1.1.2.5. kazanımında “zihinden işlem çalışmaları" ifadesi ile esnek işlem yapma ve sonucun akla yatkınlığını yargılama kategorisine ayrıca kazanımın b yönergesinde geçen "sayı ikilileri, 10’a tamamlama” gibi ifadelerin sayıların anlamı bileşeniyle ilişkili ip uçları verdiği düşünüldüğünden bu kategoriye de dahil edilmiştir.

M.1.1.2.5. Zihinden toplama işlemi yapar.

a) Toplamları 20'yi geçmeyen sayılarla zihinden işlem çalışmaları yapılır.

b) Ögrencilerin zihinden iş̧lem stratejileri geliştirmelerine imkân verilir. Örneğin sayı ikilileri, üzerine ekleme, 10'a tamamlama gibi stratejiler bu sınıf seviyesinde kullanılabilir.

Şekil 1. Sayıların anlamı ve esnek işlem yapma, sonucun akla yatkınlığını yargılama bileşenine örnek 1. Sınıf kazanımı

Aşağıdaki kazanım ise sayılarla oluşturulan ifadeleri büyüklük olarak karşılaştırmayı, küçükten büyüğe/ büyükten küçüğe doğru sıralamayı, sayıların birbirine olan uzaklıklarını karşılaştırmayı içerdiğinden sayıların büyüklüğü bileşeninde değerlendirilmiştir.

M.2.1.1.8. 100'den küçük doğal sayıların hangi onluğa daha yakın olduğunu belirler.

Şekil 2. Sayıların büyüklüğü bileşenine örnek 2. Sınıf kazanımı

Aşağıdaki kazanımda bir şeyin büyüklüğü ya da ölçüsü hakkında saymadan ve ölçüm yapmadan hızlı ve akla yatkın bir şekilde fikir yürütme olduğu için tahmin etme bileşenine dahil edilmiştir.

M.4.3.1.3. Doğrudan ölçebileceği bir uzunluğu en uygun uzunluk ölçme birimiyle tahmin eder ve tahminini ölçme yaparak kontrol eder.

Şekil 3. Tahmin etme bileşenine örnek 4. sınıf kazanımı 
Bu çalışmada güvenirliğe ilişkin odağımız yazılı bir doküman olan matematik programının betimsel analizi için çoklu kodlayıcıların görüş birliğidir. Nitel çalışmalarda kodlayıcı güvenirlik katsayıs1 = Görüş Birliği/Görüş Birliği + Görüş Ayrılığ 1 x 100 (Miles \& Huberman, 1994) hesaplanarak güvenirlik elde edildiği ve kodlayıcılar arası görüş birliğini Silverman'ın (2005) da desteklediği bildirilmektedir. $\mathrm{Bu}$ çalışmada kodlayıcı güvenirlik katsayısı; 0,923 olarak hesaplanmıştır. Dolayısıyla kodlama ve analizin güvenilir olduğu söylenebilir.

\section{Bulgular}

Tablo 2. 2018 İlkokul Matematik Ögretim Programındaki Kazanım Saylsı

\begin{tabular}{|c|c|c|c|}
\hline Siniflar & Öğrenme Alanları & Kazanım Sayıları & Toplam \\
\hline \multirow{4}{*}{1} & Sayılar ve İşlemler & 19 & \multirow{4}{*}{36} \\
\hline & Geometri & 6 & \\
\hline & Ölçme & 10 & \\
\hline & Veri İşleme & 1 & \\
\hline \multirow{4}{*}{2} & Sayılar ve İşlemler & 25 & \multirow{4}{*}{50} \\
\hline & Geometri & 8 & \\
\hline & Ölçme & 16 & \\
\hline & Veri İşleme & 1 & \\
\hline \multirow{4}{*}{3} & Sayılar ve İşlemler & 36 & \multirow{4}{*}{72} \\
\hline & Geometri & 10 & \\
\hline & Ölçme & 23 & \\
\hline & Veri İşleme & 3 & \\
\hline \multirow{4}{*}{4} & Sayılar ve İşlemler & 34 & \multirow{4}{*}{71} \\
\hline & Geometri & 12 & \\
\hline & Ölçme & 21 & \\
\hline & Veri İşleme & 4 & \\
\hline TOPLAM & & & 229 \\
\hline
\end{tabular}

Tablo 2 incelendiğinde 2018 İlkokul Matematik Öğretim Programında 1.sınıfta toplam 36, 2.sınıfta 50, 3.sinıfta 72 ve 4 .sinfta 71 kazanım olduğu görülmektedir. Diğer yandan tüm sınıf düzeylerinde sayılar ve işlemler öğrenme alanında 114 , geometri öğrenme alanında 36 , ölçme öğrenme alanında 70, veri öğrenme alanında 9 kazanım olduğu görülmektedir. 
İlkokul Matematik Öğretim Programının Sayı Duyusu Temel Bileşenlerine Göre

İncelenmesi

Tablo 3. 2018 Yılı İlkokul Matematik Öğretim Programında Sınıf Düzeyine Göre Sayı Duyusu Içeren Kazanım Sayıları

\begin{tabular}{|c|c|c|c|c|c|c|}
\hline Sınıf düzeyi & $\begin{array}{c}\text { Sayıların } \\
\text { Anlamı }\end{array}$ & $\begin{array}{c}\text { Sayıların } \\
\text { Büyüklüğü }\end{array}$ & $\begin{array}{c}\text { Esnek İşlem } \\
\text { Yapma ve } \\
\text { Sonucun Akla } \\
\text { Yatkınlığını } \\
\text { Yargılama }\end{array}$ & Tahmin Etme & TOPLAM & Yüzde(\%) \\
\hline 1 & 1 & 1 & 2 & 1 & 5 & 13.8 \\
\hline 2 & 3 & 2 & 1 & 5 & 11 & 22 \\
\hline 3 & 4 & 1 & 3 & 4 & 12 & 16.6 \\
\hline 4 & 4 & 4 & 1 & 2 & 11 & 15.4 \\
\hline
\end{tabular}

Tablo 3, 2018 yılı İlkokul Matematik Öğretim Programında Tablo 2'de verilen sınıf düzeyindeki toplam kazanım sayıları dikkate alınarak değerlendirildiğinde; 1. Sınıf kazanımlarının 5’i (\%13.8), 2. Sınıf kazanımlarının 11'i (\%22), 3. Sınıf kazanımlarının 12'si (\%16.6), 4. Sinıf kazanımlarının 11'i (\%15.4) sayı duyusu bileşenleri kapsamında belirlenmiştir. Sınıf düzeylerinin kendi içindeki kazanım yoğunluğu baz alındığında en az sayı duyusu içeren kazanım sayısının 1. Sinıfta, en fazla 2. Sinıfta olduğu görülmüştür.

Tablo 4. 2018 Yılı İlkokul Matematik Öğretim Programında Öğrenme Alanlarına Göre Sayı Duyusu İçeren Kazanım Sayıları

\begin{tabular}{|c|c|c|c|c|c|c|}
\hline $\begin{array}{c}\text { Öğrenme } \\
\text { Alanları }\end{array}$ & $\begin{array}{l}\text { Sayıların } \\
\text { Anlamı }\end{array}$ & $\begin{array}{c}\text { Sayıların } \\
\text { Büyüklüğüu }\end{array}$ & $\begin{array}{c}\text { Esnek İşlem } \\
\text { Yapma ve } \\
\text { Sonucun Akla } \\
\text { Yatkınlığını } \\
\text { Yargılama }\end{array}$ & $\begin{array}{c}\text { Tahmin } \\
\text { Etme }\end{array}$ & TOPLAM & Yüzde (\%) \\
\hline $\begin{array}{c}\text { Sayılar ve } \\
\text { İşlemler }\end{array}$ & 12 & 8 & 7 & 5 & 32 & 28.07 \\
\hline Geometri & - & - & - & - & - & - \\
\hline Ölçme & - & - & - & 7 & 7 & 10 \\
\hline Veri İşleme & - & - & - & - & - & - \\
\hline
\end{tabular}

Tablo 4, 2018 y1lı İlkokul Matematik Öğretim Programında Tablo 2'de verilen öğrenme alanlarındaki toplam kazanım sayıları dikkate alınarak değerlendirildiğinde sayı bileşenlerine 
uygun kazanımların en fazla sayılar ve işlemler öğrenme alanında bulunduğu (32; \%28.07) tespit edilmiştir. Bunun yanında ölçme öğrenme alanında sadece tahmin etme bileşeniyle ilişkilendirilmiş sayı duyusu ifadeleri $(7 ; \% 10)$ belirlenmiştir. Programda geometri ve veri işleme öğrenme alanında sayı duyusuna uygun kazanımlar tespit edilememiştir.

Ayrıca müfredatta bulunan bir kazanımın birden fazla sayı duyusu bileşenine uygun olduğu durumlar da tespit edilmiştir. Örneğin;

M.3.1.2.3. íki sayının toplamını tahmin eder ve tahminini işlem sonucuyla karşılaşı̧ıır.

a) Tahmin stratejileri kullanılır.

b) Yuvarlama, sayı çiftleri ve basamak değerleri kullanılarak tahmin stratejileri geliştirmeleri sağlanır.

Şekil 4. Birden fazla sayı duyusu bileşenine dahil edilen örnek kazanım

Şekil 4' te görüldüğü üzere 'iki sayının toplamını tahmin eder, ibaresi sayı duyusu bileşenlerinden tahmin etme bileşenine uygundur. Kazanım aynı zamanda b yönergesinde yer alan yuvarlama, sayı çiftleri stratejileri ifadeleri sayıların anlamı bileşeni ile ilgili ipuçları vermektedir (Bkz. Tablo 1).

Aşağıdaki tablolarda sınıflara ve öğrenme alanlarına göre analiz edilen kazanımlar açıkça belirtilmiştir.

Tablo 5. 2018 İlkokul Matematik Öğretim Programı Sayı Duyusu Bileşenleri ile İlişkilendirilen Kazanım Ifadeleri- 1.sinif

\begin{tabular}{|c|c|c|c|}
\hline $\begin{array}{l}\text { Sinıf } \\
\text { düzeyi }\end{array}$ & Öğrenme Alanı & $\begin{array}{l}\text { Sayı duyusu } \\
\text { Bileşeni }\end{array}$ & Kazanım ifadeleri \\
\hline \multirow{4}{*}{1} & \multirow{3}{*}{ Sayılar ve İşlemler } & Sayıların Anlamı & M.1.1.2.5. Zihinden toplama işlemi yapar. \\
\hline & & Sayıların büyüklüğü & $\begin{array}{l}\text { M.1.1.1.6. 20’ye kadar (20 dâhil) olan sayılarda verilen } \\
\text { bir sayıyı, büyüklük-küçüklük bakımından } 10 \text { sayısı ile } \\
\text { karşılaştırır. }\end{array}$ \\
\hline & & $\begin{array}{c}\text { Esnek işlem yapma } \\
\text { ve sonucun akla } \\
\text { yatkınlı̆ını } \\
\text { yargılama }\end{array}$ & $\begin{array}{l}\text { M.1.1.2.5. Zihinden toplama işlemi yapar. } \\
\text { M.1.1.3.3. Doğal sayılarda zihinden çıarma işlemi yapar. }\end{array}$ \\
\hline & Ölçme & Tahmin etme & $\begin{array}{l}\text { M.1.3.1.3. Bir nesnenin uzunluğunu standart olmayan } \\
\text { ölçme birimleri türünden tahmin eder ve ölçme yaparak } \\
\text { tahminlerinin doğruluğunu kontrol eder. }\end{array}$ \\
\hline
\end{tabular}


İlkokul Matematik Öğretim Programının Sayı Duyusu Temel Bileşenlerine Göre

İncelenmesi

Tablo 5' te 1 . Sınıf düzeyinde sayılar ve işlemler öğrenme alanı kazanımlarından 1'i sayıların anlamı, 1'i sayıların büyüklüğü, 2'si esnek işlem yapma ve sonucun akla yatkınlığını yargılama bileşeninde, ölçme öğrenme alanı kazanımlarından 1'i tahmin etme bileşeninde olmak üzere toplam 5 kazanım belirlenmiştir.

Tablo 6. 2018 İlkokul Matematik Öğretim Programı Sayı Duyusu Bileşenleri ile İlişkilendirilen Kazanım Ifadeleri- 2.sınıf

\begin{tabular}{|c|c|c|c|}
\hline $\begin{array}{c}\text { Sınıf } \\
\text { düzeyi }\end{array}$ & Öğrenme Alanı & $\begin{array}{c}\text { Sayı duyusu } \\
\text { Bileşeni }\end{array}$ & Kazanım ifadeleri \\
\hline \multirow{5}{*}{2} & \multirow{4}{*}{ Sayılar ve İşlemler } & Sayıların Anlamı & $\begin{array}{l}\text { M.2.1.2.4. Zihinden toplama işlemi yapar. } \\
\text { M.2.1.3.5. Eşit işaretinin matematiksel ifadeler arasındaki } \\
\text { "eşitlik" anlamını fark eder } \\
\text { M.2.1.2.3. İki doğal sayının toplamını tahmin eder ve } \\
\text { tahminini işlem sonucuyla karşılaştırır. }\end{array}$ \\
\hline & & Sayıların büyüklüğü & $\begin{array}{l}\text { M.2.1.1.7. 100'den küçük doğal sayılar arasında } \\
\text { karşılaştırma ve sıralama yapar. } \\
\text { M.2.1.1.8. 100'den küçük doğal sayıların hangi onluğa } \\
\text { daha yakın olduğunu belirler. }\end{array}$ \\
\hline & & $\begin{array}{l}\text { Esnek işlem yapma } \\
\text { ve sonucun akla } \\
\text { yatkınlığını } \\
\text { yargılama }\end{array}$ & M.2.1.2.4. Zihinden toplama işlemi yapar. \\
\hline & & Tahmin etme & $\begin{array}{l}\text { M.2.1.1.3. Verilen bir çokluktaki nesne sayısını tahmin } \\
\text { eder, tahminini sayarak kontrol eder. } \\
\text { M.2.1.2.3. İki doğal sayının toplamını tahmin eder ve } \\
\text { tahminini işlem sonucuyla karşılaştırır. } \\
\text { M.2.1.3.2. } 100 \text { içinde } 10 \text { 'un katı olan iki doğal sayının } \\
\text { farkını zihinden bulur. } \\
\text { M.2.1.3.3. Doğal sayılarla yapılan çıkarma işleminin } \\
\text { sonucunu tahmin eder ve tahminini işlem sonucuyla } \\
\text { karşılaştırır }\end{array}$ \\
\hline & Ölçme & Tahmin etme & $\begin{array}{l}\text { M.2.3.1.4. Uzunlukları metre veya santimetre birimleri } \\
\text { türünden tahmin eder ve tahminini ölçme sonucuyla } \\
\text { karşılaştırarak kontrol eder. }\end{array}$ \\
\hline
\end{tabular}

Tablo 6' da 2. Sınıf düzeyinde sayılar ve işlemler öğrenme alanı kazanımlarından 3’ü sayıların anlamı, 2'si sayıların büyüklüğü, 1'i esnek işlem yapma ve sonucun akla yatkınlığını yargılama bileşeninde, 4'ü tahmin etme; ölçme öğrenme alanı kazanımlarından 1'i tahmin etme bileşeninde olmak üzere toplam 11 kazanım belirlenmiştir. 
Tablo 7. 2018 İlkokul Matematik Öğretim Programı Sayı Duyusu Bileşenleri ile İlişskilendirilen Kazanim Ifadeleri- 3.sinif

\begin{tabular}{|c|c|c|c|}
\hline $\begin{array}{c}\text { Sinıf } \\
\text { düzeyi }\end{array}$ & Öğrenme Alanı & $\begin{array}{l}\text { Sayı duyusu } \\
\text { Bileşeni }\end{array}$ & Kazanım ifadeleri \\
\hline \multirow{5}{*}{3} & \multirow{4}{*}{ Sayılar ve İşlemler } & Sayıların Anlamı & $\begin{array}{l}\text { M.3.1.2.3. İki sayının toplamını tahmin eder ve tahminini } \\
\text { işlem sonucuyla karşılaştııır. } \\
\text { M.3.1.2.4. Zihinden toplama işlemi yapar. } \\
\text { M.3.1.3.2. İki basamaklı sayılardan 10'un katı olan iki } \\
\text { basamaklı sayıları, üç basamaklı 100'ün katı olan doğal } \\
\text { sayılardan 10'un katı olan iki basamaklı doğal sayıları } \\
\text { zihinden çıkarır } \\
\text { M.3.1.3.3. Doğal sayılarla yapıllan çıkarma işleminin } \\
\text { sonucunu tahmin eder, tahminini işlem sonucuyla } \\
\text { karşıslaştırır. }\end{array}$ \\
\hline & & Sayıların büyüklüğü & $\begin{array}{l}\text { M.3.1.1.4. En çok üç basamaklı doğal sayıları en yakın } \\
\text { onluğa ya da yüzlüğe yuvarlar. }\end{array}$ \\
\hline & & $\begin{array}{c}\text { Esnek işlem yapma } \\
\text { ve sonucun akla } \\
\text { yatkınlığını } \\
\text { yargılama }\end{array}$ & $\begin{array}{c}\text { M.3.1.2.4. Zihinden toplama işlemi yapar. } \\
\text { M.3.1.3.2. İki basamaklı sayılardan 10'un katı olan iki } \\
\text { basamaklı sayıları, üç basamaklı 100’ün katı olan doğal } \\
\text { sayıllardan 10'un katı olan iki basamaklı doğal sayıları } \\
\text { zihinden çıkarır. } \\
\text { M.3.1.3.3. Doğal sayılarla yapıılan çıkarma işleminin } \\
\text { sonucunu tahmin eder, tahminini işlem sonucuyla } \\
\text { karşılaştırır. }\end{array}$ \\
\hline & & Tahmin etme & $\begin{array}{l}\text { M.3.1.2.3. İki sayının toplamını tahmin eder ve tahminini } \\
\text { işlem sonucuyla karşılaştırır. }\end{array}$ \\
\hline & Ölçme & Tahmin etme & $\begin{array}{l}\text { M.3.3.3.2. Bir alanı, standart olmayan alan ölçme } \\
\text { birimleriyle tahmin eder ve birimleri sayarak tahminini } \\
\text { kontrol eder. } \\
\text { M.3.3.6.2. Bir nesnenin kütlesini tahmin eder ve ölçme } \\
\text { yaparak tahmininin doğruluğunu kontrol eder. } \\
\text { M.3.3.7.2. Bir kaptaki sıvının miktarını litre ve yarım litre } \\
\text { birimleriyle tahmin eder ve ölçme yaparak tahmininin } \\
\text { doğruluğunu kontrol eder }\end{array}$ \\
\hline
\end{tabular}

Tablo 7' de 3. Sınıf düzeyinde sayılar ve işlemler öğrenme alanı kazanımlarından 4'ü sayıların anlamı, 1'i sayıların büyüklügü, 3'ü esnek işlem yapma ve sonucun akla yatkınlığını yargılama bileşeninde, 1'i tahmin etme; ölçme öğrenme alanı kazanımlarından 3'ü tahmin etme bileşeninde olmak üzere toplam 12 kazanım belirlenmiştir. 
İlkokul Matematik Öğretim Programının Sayı Duyusu Temel Bileşenlerine Göre

İncelenmesi

Tablo 8. 2018 İlkokul Matematik Öğretim Programı Sayı Duyusu Bileşenleri ile İlişkilendirilen Kazanım Ifadeleri- 4.sınıf

\begin{tabular}{|c|c|c|c|}
\hline $\begin{array}{c}\text { Sınıf } \\
\text { düzeyi }\end{array}$ & Öğrenme Alanı & $\begin{array}{l}\text { Sayı duyusu } \\
\text { Bileşeni }\end{array}$ & Kazanım ifadeleri \\
\hline \multirow{4}{*}{4} & \multirow[t]{3}{*}{ Sayılar ve İşlemler } & Sayıların Anlamı & $\begin{array}{c}\text { M.4.1.1.3. } 4,5 \text { ve } 6 \text { basamaklı doğal sayıların bölüklerini } \\
\text { ve basamaklarını, basamaklarındaki rakamların } \\
\text { basamak değerlerini belirler ve çözümler. } \\
\text { M.4.1.2.2. İki doğal sayının toplamını tahmin eder ve } \\
\text { tahminini işlem sonucu ile karşılaştırır. } \\
\text { M.4.1.5.7. Aralarında eşitlik durumu olan iki } \\
\text { matematiksel ifadeden birinde verilmeyen değeri belirler } \\
\text { ve eşitliğin } \\
\text { sağlandığını açıklar } \\
\text { M.4.1.5.8. Aralarında eşitlik durumu olmayan iki } \\
\text { matematiksel ifadenin eşit olması için yapılması gereken } \\
\text { işlemleri } \\
\text { açıklar. }\end{array}$ \\
\hline & & Sayıların büyüklüğü & $\begin{array}{l}\text { M.4.1.1.4. Doğal sayıları en yakın onluğa veya yüzlüğe } \\
\text { yuvarlar } \\
\text { M.4.1.1.5. En çok altı basamaklı doğal sayıları } \\
\text { büyük/küçük sembolü kullanarak sıralar } \\
\text { M.4.1.6.2. Birim kesirleri karşılaştırır ve sıralar. } \\
\text { M.4.1.6.4. Paydaları eşit olan en çok üç kesri karşılaştırır. }\end{array}$ \\
\hline & & $\begin{array}{c}\text { Esnek işlem yapma } \\
\text { ve sonucun akla } \\
\text { yatkınlığını } \\
\text { yargılama }\end{array}$ & $\begin{array}{l}\text { M.4.1.2.2. İki doğal sayının toplamını tahmin eder ve } \\
\text { tahminini işlem sonucu ile karşılaştırır. }\end{array}$ \\
\hline & Ölçme & Tahmin etme & $\begin{array}{l}\text { M.4.3.1.3. Doğrudan ölçebileceği bir uzunluğu en uygun } \\
\text { uzunluk ölçme birimiyle tahmin eder ve tahminini ölçme } \\
\text { yaparak kontrol eder. } \\
\text { M.4.3.6.4. Bir kaptaki sıvının miktarını, litre ve mililitre } \\
\text { birimleriyle tahmin eder ve ölçme yaparak tahminini } \\
\text { kontrol eder }\end{array}$ \\
\hline
\end{tabular}

Tablo 8' de 4. Sınıf düzeyinde sayılar ve işlemler öğrenme alanı kazanımlarından 4'ü sayıların anlamı, 4'ü sayıların büyüklüğü, 1'i esnek işlem yapma ve sonucun akla yatkınlığını yargılama bileşeninde; ölçme öğrenme alanı kazanımlarından 2'si tahmin etme bileşeninde olmak üzere toplam 11 kazanım belirlenmiştir.

Tablo 5, 6, 7, 8’ de araştırmanın şeffaflığı açısından, programda sayı duyusu bileşenleriyle ilişkilendirilen kazanımlara yer verilirken, kazanım yönergelerine yer işgal etmemesi bakımından yer verilmemiştir. Ancak kazanımların yönerge ifadeleri de dikkate alınarak sayı duyusu bileşenleri analiz yapılmıştır. 
Çetin \& Öztürk (2020)

Tablolarda görüldüğü üzere en fazla sayıların anlamı (12) ve tahmin etme bileşeniyle (12) ilişkilendirilmiş kazanımlar mevcuttur.

\section{Sonuç Tartışma ve Öneriler}

İlkokul Matematik dersine ait 2018 yılı Matematik Öğretim Programında yer alan kazanımlar sayı duyusu temel bileşenlerine göre incelenmiştir. Sayı duyusu kavram olarak programda yer almamasına rağmen sayı duyusunu geliştiren sayı ikilileri, 10'a tamamlama, üzerine sayma, geriye sayma, tahmin, yuvarlama, basamak değerleri, sayıları parçalama gibi ifadelere programda yer verilmektedir.

İlkokul Matematik Programını inceleyen Çekirdekçi (2015) çalışmasında, 2012 yılındaki matematik öğretim programında yer alan 4.sınıf kazanımlarının 14 tanesinin sayı duyusu ile ilişkili olduğu sonuca ulaşmıştır. Bu 14 kazanımın Reys vd. (1999) tarafından tanımlanan sayı duyusu bileşenlerinden 'sayıların anlamını bilme, zihinden hesaplama ve hesaplamada esneklik, ölçüm referansları' bileşenleri ile ilgili olduğu görülmektedir. 2018 yılındaki güncel müfredatta ise 4 . Sınıf kazanımlarının 11'i sayı duyusu bileşenleriyle ilişkilendirilmiş ve diğer sınıf düzeyleriyle birlikte toplam 39 kazanımın sayı duyusu dahilinde ele alınmıştır. Sayıların anlamı (12), sayıların büyüklüğü (8), esnek işlem yapma ve sonucun akla yatkınlığını yargılama (7), tahmin etme (12) bileşenleriyle ile ilişkilendirilmiş kazanımlar, doğrudan sayı duyusu ifadesinin geçmediği halde ipucu ifadelerden yola çıkarak ortaya çıkarılmıştır. Benzer şekilde Harç (2010) tarafından ülkelerin müfredatlarının incelediği çalışmada, genel olarak kazanımlarda sayı duyusu kavramının doğrudan belirtilmediği ancak sayı duyusu bileşenlerinin içerisinde yer aldığı görülmektedir. 2007 yılı Türkiye müfredatının 1. ve 6. sınıflar arasındaki kazanımlardan 25 tanesinde sayı duyusu bileşenlerine rastlanmaktadır (Harç, 2010). 2018 müfredatının incelenen 1-4. Sınıf düzeyi göz önünde bulundurulduğunda, 2007 yılına göre sayı duyusu ile ilişkilendirilen kazanımların niceliksel olarak artı̧̧ gösterdiği söylenebilir.

Çalışmada kazanım yoğunluğu esas alındığında, en fazla sayılar ve işlemler öğrenme alanında (\%28.07) ve 2. Sınıf düzeyinde (\%22) sayı duyusu bileşenine uygun kazanım olduğu tespit edilmiştir. $\mathrm{Bu}$ durum matematik dersinin sarmal yapısından kaynaklandığı söylenebilir. Öğrencinin bir ölçüm ile ilgili tahminde bulunabilmesi için geçmiş öğrenmelerinde ölçüm sonucunu ifade etmek için kullanacağı sayıyı ve niceliğini iyi kavraması gerekmektedir. Sayı 
İlkokul Matematik Öğretim Programının Sayı Duyusu Temel Bileşenlerine Göre İncelenmesi duyusu bileşenlerine uygun kazanımların öğrenme alanları dağılımı incelendiğinde Gülbağcı Dede (2015) ve Çekirdekçi (2015) ile benzer olarak sayı duyusu bileşenlerine uygun kazanımlar sayılar ve işlemler ile ölçme öğrenme alanlarında bulunmuştur. Bu açıdan bizim çalışmamızda da sayı duyusuna dahil edilen bazı kazanımların ölçme öğrenme alanından tespit edilmesi bakımından tutarlılık göstermektedir.

Yaşam boyunca kullanılacak olan matematik becerisinin büyük bir kısmı matematik öğretim programında belirlenen kazanımlar doğrultusunda gerçekleşmektedir. Okula sayı ve sayma becerileriyle gelen öğrencilerin bu temel becerilerden daha üst düzeyde bilgi geliştirmeleri öğretmenlerin görevidir (TTKB, 2006: akt: Osmanoğlu, 2016). Matematik öğretiminde önemli bir yere sahip olan sayı duyusunun programda daha belirgin yer bulması eğitim-öğretim sürecini planlayan öğretmenlerin temel sayı öğretiminden daha üst düzey bir beceri kabul edilen sayı duyusuna dikkatlerini çekecektir. Ders planlamalarının bu yönde yapılması sayı duyusu gelişimi için oldukça yarar sağlayacaktır. Gelecekte yapılması öngörülen ya da revize edilecek ulusal ve farklı ülkelerin matematik programlarının kritik matematik beceriler açısından incelendiği ve karşılaştırıldığı çalışmalara yer verilmesi önerilmektedir.

\section{Yazar Katkı Beyanı:}

1. Hatice Çetin: Kavramsallaştırma, kuramsal çerçeve, metodoloji, kodlama, veri analizi, ön taslak yazımı ve düzenleme.

2. Şeyma Öztürk: Kodlama, veri analizi, inceleme-yazma ve düzenleme.

\section{Kaynakça}

Baki, A. (2019). Matematiği öğretme bilgisi. 2. Baskı. Ankara: Pegem Akademi Yayıncılık.

Bayak, N. (2016). Sınıf öğretmenlerinin sayı duyusu düzeyleri ve ilkokul matematik öğretiminde kullanma durumları. Yüksek Lisans tezi. Pamukkale Üniversitesi.

Can, D. (2017). İlkokul dördüncü sınıf öğrencilerinin sayı duyularının bağlam temelli ve bağlam temelli olmayan problem durumlarında incelenmesi. Doktora Tezi. Hacettepe Üniversitesi. 
Cheng, Q., \& Wang, J. (2012). Curriculum opportunities for number sense development: a comparison of first-grade textbooks in china and the united states. International Journal for Mathematics Teaching and Learning, 52.

Creswell, J. W. (2015). Nitel araştırma yöntemleri: Beş yaklaşıma göre nitel araştırma ve araştırma deseni (3. Baskıdan Çeviri). Çeviri Editörleri: M. Bütün ve SB Demir). Ankara: Siyasal Yayın Dağıtım.

Crouch, R., \& Haines, C. (2004). Mathematical modelling: transitions between the real world and the mathematical model. International Journal of Mathematical Education in Science and Technology, 35(2), 197-206.

Çekirdekçi, S. (2015). İlkokul 4. sınıf öğrencileri için sayı hissi testinin geliştirilerek öğrencilerin sayı hislerinin incelenmesi. Doktora tezi. Marmara Üniversitesi, Eğitim Bilimleri Enstitüsü.

Deniz, D. (2014). Ortaöğretim matematik öğretmenlerinin matematiksel modelleme yöntemine uygun etkinlik oluşturabilme ve uygulayabilme yeterlikleri, Doktora Tezi. Erzurum: Atatürk Üniversitesi.

Greeno, J. G. (1991). Number sense as situated knowing in a conceptual domain. Journal for research in mathematics education, 22(3), 170-218.

Gülbağcı Dede, H. (2015). İlköğretim ve ortaöğretim matematik öğretmen adaylarının sayı hissinin incelenmesi. Doktora Tezi. İstanbul: Marmara Üniversitesi.

Gülbağcı Dede, H., \& Şengül, S. (2016). İlköğretim ve ortaöğretim matematik öğretmen adaylarının sayı hissinin incelenmesi. Turkish Journal of Computer and Mathematics Education, 7(2), 285-303.

Güven, B., \& Özçelik, Ç. (2017). İlkokul matematik dersine yönelik gerçekleştirilen lisansüstü eğitim tez çalışmalarına ilişkin bir inceleme. Eğitimde Kuram ve Uygulama, 13(4), 693714.

Harç, S. (2010). 6.Sınıf öğrencilerinin sayı duygusu kavramı açsından mevcut durumlarının analizi. Yüksek Lisans Tezi. İstanbul: Marmara Üniversitesi,Eğitim Bilimleri Enstitüsü.

Howden, H. (1989). Teaching number sense. The Arithmetic Teacher, 36(6), 6.

Karabey, B., Tunal1, C., Olkun, S., \& Ergut, G. (2019). . 2009-2013-2017 Ortaokul matematik öğretim programlarının sayı duyusu bileşenlerine göre karşılaştırılması. Abant İzzet Baysal Üniversitesi Eğitim Fakültesi Dergisi, 19(4), 1760-1774.

Mcintosh, A., Reys, B., \& Reys, R. (1992). A proposed framework for examining basic number sense. For the Learning of Mathematics, 12(3), 2-8. 
İlkokul Matematik Öğretim Programının Sayı Duyusu Temel Bileşenlerine Göre İncelenmesi

MEB. (2018). Matematik dersi öğretim programı (ilkokulve ortokul 1,2,3,4,5,6,7. ve 8. sinıflar. Ankara: Milli Eğitim Bakanlı̆̆ı.

Miles, M. B., \& Huberman, A. M. (1994). Qualitative data analysis: An expanded sourcebook. Sage.

NCTM. (1989). Curriculum and evaluation standarts for council of teachers of mathematics. Reston.

Osmanoğlu, A. (2016). İlköğretim Matematik Dersi Programlarının Sayılar Öğrenme Alanı Karşılaştırması. Özmantar, M. F., ve Öztürk, A. (Eds.). (2016). Reform ve değişim bă̆lamında ilkokul matematik ögretim programları. Pegem Akademi Yayınları.

Peker, E. S. (2019). Ortaokul sekizinci snıf öğrencilerinin sayı duyusu performanslarının incelenmesi. Yüksek Lisans Tezi. Uşak Üniversitesi.

Reys, R., Reys, B., Emanuelsson, G., Johansson, B., McIntosh, A., ve Yang, D. C. (1999). Assessing number sense of students in Australia, Sweden, Taiwan, and the United States. School Science and Mathematics, 99(2), 61-70.

Silverman, D. (2005). Instances or sequences? Improving the state of the art of qualitative research. In Forum Qualitative Sozialforschung/Forum: Qualitative Social Research , 6(3), 30.

Şengül, S. (2013). Sınıf öğretmeni adaylarının kullandıkları sayı duyusu stratejilerinin belirlenmesi. Kuram ve Uygulamada Eğitim Bilimleri, 13(3), 1951-1974.

Umay, A., Akkuş-Çıkla, O., \& Duatepe, A. (2006). Matematik dersi 1. - 5. sınıf öğretim programlarının NCTM prensip ve standartlarına göre incelenmesi. Hacettepe Üniversitesi Ĕ̌itim Fakültesi Dergisi, 31(31), 198-211.

van De Walle, J. A., Karp, K. S., \& Bay-Williams, J. M. (2014). Illkokul ve ortaokul matematiği: gelişimsel yaklaşımla öğretim. Nobel Akademik Yayıncılık.

Yang, D. C. (1995). Number sense performance and strategies possessed by sixth and eighth grade students in Taiwan. Dissertation.University of Missouri-Columbia.

Yang, D. C. (2005). Number sense strategies used by 6th-grade students in Taiwan. Educational Studies, 31(3), 317-333.

Yang, D. C. (2007). Investigating the strategies used by pre-service teachers in Taiwan when responding to number sense questions. School Science and Mathematics, 107(7), 293-301.

Yang, D. C., Hsu, C. J., \& Huang, M. C. (2004). A study of teaching and learning number sense for sixth grade students in Taiwan. International Journal of Science and Mathematics Education, 2(3), 407-430. 
Çetin \& Öztürk (2020)

Yarımkaş, C. (2019). Sınıf öğretmeni adaylarının sayı hissinin incelenmesi. Doktora tezi. Kastamonu Üniversitesi.

Yıldırım, A., \& Şimşek, H. (2006). Sosyal bilimlerde nitel araştırma. Ankara: Seçkin Yayıncılık. 